\title{
PROSES AUDIT DALAM AUDIT SISTEM INFORMASI
}

\author{
Aris Suwandi \\ 175100054 \\ Fakultas Komputer \\ arissuwandi.student@umitra.ac.id
}

\begin{abstract}
Abstrak Kompetensi Semakin tingginya kebutuhan organisasi terhadap sistem informasi mendorong adopsinya di berbagai aspek organisasi. Pengendalian terhadap sistem informasi menjadi krusial, untuk mengetahui apakah pengendalian tersebut efektif diperlukanlah audit.
\end{abstract}

Kata Kunci : proses, audit sistem informasi

A. PENDAhUluan

Audit Sistem Informasi adalah proses pengumpulan dan pengevaluasian bukti-bukti untuk membuktikan dan menentukan 
apakah sistem aplikasi komputerisasi yang digunakan telah menetapkan dan menerapkan sistem pengendalian intern yang memadai, apakah aset organisasi sudah dilindungi dengan baik dan tidak disalah gunakan, apakah mampu menjaga integritas data, kehandalan serta efektifitas dan efisiensi penyelenggaraan sistem informasi berbasis komputer.

Proses Audit dalam konteks teknologi informasi adalah memeriksa apakah sistem informasi berjalan semestinya. Tujuh langkah proses audit sistem informasi yaitu:

a)Implementasikan sebuah strategi audit berbasis manajemen resiko serta control practice yang dapat disepakati oleh semua pihak

b) Tetapkan langkah-langkah audit yang rinci

c) Gunakan fakta atau bahan bukti yang cukup, handal, relevan, serta bermanfaat

d)Buat laporan beserta kesimpulan berdasarkan fakta yang dikumpulkan
e)Telaah apakah tujuan audit tercapai

f) Sampaikan laporan kepada pihak yang berkepentingan

g)Pastikan bahwa organisasi mengimplementasikan managemen resiko serta control practice.

\section{B. PEMBAHASAN / STUDI KASUS}

Pengendalian

Audit sistem informasi berangkat dari paradigma pengendalian = pengendalian oleh pengelolaan (manajemen), dimana pengendalian pengelolaan tersebut dimulai dengan tata kelola, pengelola tertinggi dapat mengendalikan semua hal dan pengendalian tersebut ditegakkan. Tetapi kondisi lingkungan bisnis saat ini menyarankan paradigma yang lebih tepat adalah perbaikan secara terus menerus dengan fokus pada pengendalian pada pemilik proses.

Identifikasi

Aktivitas Kunci Produk dan layanan utama perlu diidentifikasi. Hal ini berkaitan erat dengan 
pemahaman terhadap kebutuhan konsumen, kompetitor dan respon mereka (Pemahaman terhadap KPA). $\mathrm{KPA}=$ Key Performance Area

Memutuskan Strategi

Pengendalian

Resiko dikaitkan dengan kemungkinan kejadian atau keadaan yang dapat merugikan dan mengancam pencapaian tujuan maupun sasaran organisasi. Resiko diyakini tidak dapat dihilangkan, resiko dapat dikurangi melalui manajemen resiko.

Setelah analisa resiko selesai manajemen berada dalam posisi untuk memutuskan mana aktifitas yang harus dipastikan, mana resiko yang dapat dikelola, mana resiko yang harus dipindahkan. Sasaran pelaksanaan manajemen resiko adalah untuk mengurangi resiko yang berbeda-beda terkait dengan bidang yang telah dipilih pada tingkat yang dapat diterima oleh masyarakat.
Peran Audit

Audit sistem informasi dapat dilakukan oleh pihak internal, eksternal maupun pemerintah. Proses audit dirancang untuk menentukan bagian mana yang harus diaudit dengan menggunakan parameter: 1 . Control Strategy Assessment 2. Control Adequacy and Effectiveness 3. Performance Quality Assessment 4. Unit Performance Reporting 5. Following Up Overall the standards of audit performance must be up to a professional level (misal mengikuti ISACA standards).

Profesionalisme

Tugas kritikal pada audit sistem informasi adalah pada saat mengkomunikasikan hasil audit kepada manajer kunci dan pihak yang berkepentingan.

Untuk menunjukkan profesionalisme, audit sistem informasi hendaknya mengikuti kode etik dan standar yang ada (dalam hal ini ISACA Code of Professional Ethics dan ISACA IS 
Auditing Standards).

Regulasi, Pengendalian dan

Standar Akreditasi dan

standarisasi

audit sistem informasi harus disediakan oleh pihak internal atau oleh pihak lain untuk memastikan pengamanan dan pengendalian memadai. Beberapa metode evaluasi untuk menentukan kecukupan tersedia, seperti ITSEC, TCSEC, dan ISO 9000 dengan menggunakan standar seperti COBIT (Control Objectives for Information and Related Technology), ISO 17799, ITIL (IT Infrastructure Library), coso Internal Control-Integrated Framework dan cOSO Enterprise Risk Management- Integrated Framework, dan sebagainya.

\section{B. KESIMPULAN}

Dari penulisan ini dapat disimpulkan bahwa Audit Sistem Informasi adalah proses pengumpulan dan pengevaluasian bukti-bukti untuk membuktikan dan menentukan apakah sistem aplikasi komputerisasi yang digunakan telah menetapkan dan menerapkan sistem pengendalian intern yang memadai, apakah aset organisasi sudah dilindungi dengan baik dan tidak disalah gunakan, apakah mampu menjaga integritas data, kehandalan serta efektifitas dan efisiensi penyelenggaraan sistem informasi berbasis komputer.

\section{DISKUSI}

Saya bersama teman saya bernama Rudi mendiskusikan tentang contoh ini dengan sangat baik Hasil diskusi dari materi ini adalah Penulis hanya bisa memberi saran kepada pembaca bahwasahnya konsep audit sistem informasi yaitu terdiri dari tujuan audit sampai dengan proses audit sistem informasi itu sendiri baik itu berbasis risiko, berbasis kendali serta berbasis komputer. 


\section{REFERENCE}

[1] O. M. Febriani and A. S. Putra, "Sistem Informasi Monitoring Inventori Barang Pada Balai Riset Standardisasi Industri Bandar Lampung," J. Inform., vol. 13 , no. 1, pp. 90-98, 2014.

[2] A. S. Putra, "Paperplain: Execution Fundamental Create Application With Borland Delphi 7.0 University Of Mitra Indonesia," 2018.

[3] A. S. Putra, "2018 Artikel Struktur Data, Audit Dan Jaringan Komputer," 2018.

[4] A. S. Putra, "ALIAS MANAGER USED IN DATABASE DESKTOP STUDI CASE DB DEMOS."

[5]
A.
$\mathrm{S}$.
Putra, “COMPREHENSIVE SET OF PROFESSIONAL FOR DISTRIBUTE COMPUTING."

[6] A. S. Putra, "DATA ORIENTED RECOGNITION IN BORLAND DELPHI 7.0."
[7] A. S. Putra, "EMBARCADERO DELPHI XE 2 IN GPUPOWERED FIREMONKEY APPLICATION."

[8] A. S. Putra, "HAK ATAS KEKAYAAN INTELEKTUAL DALAM DUNIA TEKNOLOGY BERBASIS REVOLUSI INDUSTRI 4.0."

[9] A. S. Putra, "IMPLEMENTASI PERATURAN PERUNDANGAN UU. NO 31 TAHUN 2000 TENTANG DESAIN INDUSTRI BERBASIS INFORMATION TECHNOLOGY."

[10] A S. Putra, "IMPLEMENTATION OF PARADOX DBASE."

[11] A. S. Putra, "IMPLEMENTATION OF TRADE SECRET CASE STUDY SAMSUNG MOBILE PHONE." [12] A. S. Putra, “IMPLEMENTATION PATENT FOR APPLICATION WEB BASED CASE STUDI WWW. PUBLIKLAMPUNG. COM."
A.
$\mathrm{S}$.
Putra, 
“IMPLEMENTATION SYSTEM FIRST TO INVENT IN DIGITALLY INDUSTRY."

[14] A. S. Putra, "MANUAL REPORT \& INTEGRATED DEVELOPMENT

ENVIRONMENT BORLAND DELPHI 7.0."

[15] A. S. Putra, "PATENT AS RELEVAN SUPPORT RESEARCH."

[16] A. S. Putra, "PATENT FOR RESEARCH STUDY CASE OF APPLE. Inc."

[17] A. S. Putra, "PATENT PROTECTION FOR APPLICATION INVENT."

[18] A. S. Putra, "QUICK REPORT IN

PROPERTY PROGRAMMING."

[19] A. S. Putra, "REVIEW CIRCUIT LAYOUT COMPONENT REQUIREMENT ON ASUS NOTEBOOK."

[20] A. S. Putra, "REVIEW TRADEMARK PATENT FOR INDUSTRIAL TECHNOLOGY BASED 4.0."

[21] A. S. Putra, "TOOLBAR
COMPONENT PALLETTE IN OBJECT ORIENTED PROGRAMMING."

[22] A. S. Putra, "WORKING DIRECTORY SET FOR PARADOX 7."

[23] A. S. Putra, "ZQUERY CONNECTION IMPLEMENTED PROGRAMMING STUDI CASE PT. BANK BCA Tbk."

[24] A. S. Putra, D. R. Aryanti, and I. Hartati, "Metode SAW (Simple Additive Weighting) sebagai Sistem Pendukung Keputusan Guru Berprestasi (Studi Kasus: SMK Global Surya)," in Prosiding Seminar Nasional Darmajaya, 2018, vol. 1, no. 1, pp. 85-97.

[25] A. S. Putra and O. M. Febriani, “Knowledge Management Online Application in PDAM Lampung Province," in Prosiding International conference on Information Technology and Business (IC/TB), 2018, pp. 181-187.

[26] A. S. Putra, O. M. Febriani, 
and B. Bachry, "Implementasi Genetic Fuzzy System Untuk Mengidentifikasi Hasil Curian Kendaraan Bermotor Di Polda Lampung," SIMADA (Jurnal Sist. Inf. dan Manaj. Basis Data), vol. 1, no. 1, pp. 21-30, 2018.

[27] A. S. Putra, H. Sukri, and K. Zuhri, "Sistem Monitoring Realtime Jaringan Irigasi Desa (JIDES) Dengan Konsep Jaringan Sensor Nirkabel," IJEIS (Indonesian J.
Electron. Instrum. Syst., vol. 8, no. 2, pp. 221-232.

[28] D. P. Sari, O. M. Febriani, and A. S. Putra, "Perancangan Sistem Informasi SDM Berprestasi pada SD Global Surya," in Prosiding Seminar Nasional Darmajaya, 2018, vol. 1, no. 1, pp. 289-294. 